\title{
Negotiating frames in bilingual classroom discourse
}

\author{
Elin Fredsted \\ Universität Flensburg, Institut für dänische Sprache und Literatur, Auf dem Campus 1, D-24943 Flensburg, \\ Germany \\ E-mail: fredsted@uni-flensburg.de
}

\section{Introduction}

It is well-known that socio-pragmatic motivations may cause speakers to choose a certain language code or mode or to shift to another language in conversations among bilinguals. Numerous theories have dealt with this phenomenon, among others Gumperz' $(1982,1992)$ theory of situational and metaphorical code switching, Myers-Scotton's (1993, 1998, 2002) distinction between marked and unmarked language choice, and Auer's (1995) conversational view on code switching as "construction of otherness".

In a research project (2004-2006) on bilingual language usage among adolescents in the German-Danish border area ("Bilingualer Sprachgebrauch bei Jugendlichen"), we found various pragmatic reasons for code switching which can be categorised in terms of four descriptive labels:

1. Orientation to the speaker's/hearer's language usage, such as individual level of competence

- $\quad$ Filling of lexical gaps (e.g. due to conflicting language choice or mismatches among components of a domain).

- $\quad$ Metalinguistic strategies and speech elaboration such as reiteration of content in another language, repetitions, self-repair, other-repair, negotiation of words and meanings.

- $\quad$ Use of discourse markers, gambits and hesitation phenomena (e.g. in order to gain processing time).

\section{Instrumental recontextualisation and orientation to discourse}

- $\quad$ Quotation of speech, "virtual" quotations, setting off quotations and narratives.

- $\quad$ Emphasis, foregrounding/backgrounding, creation of contrast.

- $\quad$ Framing or re-framing a speech situation.

- $\quad$ Bipartite structures (topic-comment, premise-conclusion).

- $\quad$ Indicating that something new follows (recontextualisation):

- Change of mode and illocution (e.g. side sequences, side comments).

- Change of key and register.

- Topic shift.

- Change of activity type. 


\section{Interactional recontextualisation}

- $\quad$ Orientation to the addressee (accommodation).

- $\quad$ Marking of disagreement or taking back control via non-accommodation.

- $\quad$ Change of social role.

\section{Language games}

- $\quad$ Extended use of both convergence and code switching in a humorous and playful manner, also used subversively to deconstruct (expected) monolinguistic norms.

Results of this project have been presented in two $\mathrm{PhD}$-dissertations and other publications focussing mainly on structural analysis and on language games (Fredsted 2008a, 2008b; Kühl 2008; Westergaard 2008). In this paper, I would like to focus on examples of interactional recontextualisation which imply a change of language mode, a change of social role and "footing", marking disagreement or taking back control by shifting to one's stronger language and thereby diverging from the expected language of the institution. Only a limited part of our data corpus from a German minority school in Denmark will be presented in this paper.

In the research project, we chose the method of participatory observations of daily life communication and recordings of authentic and almost authentic conversations over half a year (January - June 2004). The conversations presented here, took place between teachers and students of the German minority in Denmark ${ }^{1}$ in school settings, placing the dominance on the side of the teacher. The data were collected from 29 students and their teachers in the $6^{\text {th }}$ and $7^{\text {th }}$ grade. Five students were late sequential bilinguals with German as their L1 and South Jutish or Standard Danish as their L2. Most of them (24) had South Jutish as their L1 and Standard German as their L2, but in this group, the students were early sequential (and almost) balanced bilinguals with Standard German as school language and the classic dialect South Jutish as variety of colloquial speech. Standard Danish is also the subject of teaching from the first grade onwards. These children are thus confronted with the following three language varieties in their daily routine at school: two high-prestige, standardised language varieties, namely Standard Danish and Standard German, and one low-prestige, nonstandardised language variety, namely the classic dialect South Jutish. (From grade 5 onwards, the students learn English as a foreign language, as well.)

If one regards the three languages involved from a socio-linguistic point of view, one could claim that generally the standard varieties are the prestigious language varieties of the area and this is, in fact, the dominant view of sociolinguists in Denmark. The official school language is German and the standard varieties of German and Danish are supposed to be the prestigious language varieties. However, what we found went in a somewhat different direction: contrary to most sociolinguistic predictions, we can state that the students' preferred language within the peer-group was South Jutish. The South Jutish variety spoken in this area is a classic, locally restricted Danish dialect, which shows a considerable divergence to Standard Danish concerning lexicon, morpho-syntax, and phonology so that one might regard it as a language in its own right (Fredsted 2003; Westergaard 2008). In its most "genuine", classic form - as spoken by these students - it is not understandable to people from the northern and eastern part of Denmark (comparable to Low German in Germany). More "recent" regional varieties of South Jutish show considerably more convergence towards Standard Danish.

Maegaard (2001a, 2001b) conducted a sociolinguistic analysis through interviews and matched-guise tests among adolescents in a neighbouring town. Her research among students 
- predominantly belonging to the majority population - shows results that differ from ours, namely that the students claim to appreciate their local dialect, but, at the same time, they assess speakers of this dialect as being not very interesting, lacking self confidence and ambition, and having a low level of education and low intelligence. Against this background, I will offer an explanation as to why the local variety in the study presented here seems to win out against more overtly prestigious varieties in the language usage of the adolescents of the German minority.

My hypothesis is that these students (and some of their teachers) use their dialect (South Jutish) to take a step out of the situational frame of the hegemonic culture of classroom discourse in order to negotiate conditions on more "equal" terms outside the given constellation of dominance. Some of the teachers use the same shift of language code in order to show emotional engagement or solidarity, or in order to offer the students help.

A close analysis reveals that this shift of language code (from German to Danish SJ) does not indicate a shift between national cultures or identities, but instead a shift from a formal and institutional frame to an informal, less hegemonic frame. National implications of the language shift are not made explicit by the participants themselves.

\section{Interactional recontextualisation}

\subsection{Accommodation}

The overall language choice in these students' bilingual conversations goes in the direction of accommodation to the addressee. One might call this the unmarked linguistic choice (cf. Myers-Scotton 1993, 1998, 2002). The speaker accommodates to the language which the addressee prefers or understands. In conversations among bilinguals, code switching may be the unmarked choice because the interlocutors are all bilingual, and the bilingual mode becomes the default mode of expression (Grosjean 2001).

In the examples below, the following notations indicate to which group the speaker belongs:

[1] nearly balanced bilinguals with SJ as their L1, German as early L2 / or German and SJ as double L1;

[2] late sequential bilinguals with German L1, SJ as their L2; and

[3] L2 learners of Standard Danish with German as L1.

Regular fonts mark German, italics mark South Jutish, and underlined italics mark Standard Danish. Linguistic convergences (German - South Jutish) are marked in bold.

\section{Peer group conversation}

It is not at all surprising that the students accommodate to their peers. In most of the peer groups of the two school classes, we find a conventionalised pattern of language usage: peer group conversations among students with South Jutish dialect as their L1 (marked as [1] in the transcripts) will predominantly be in South Jutish with quite frequent insertions from German (one insertion every 50 seconds, on average). But as soon as one of the group members is a person with German as his/her L1 (with low or no proficiency in the SJ dialect, marked in the transcripts as [2] or [3]), the group will accommodate and address this person in German. In other words, in dialogues between a person with South Jutish as L1 and a person with German as L1, the conversation will be in German as the unmarked choice.

On the other hand, we also find students with German as their L1 who accommodate to the South Jutish dialect in peer group conversations. In the following example, Y (with German 
L1) accommodates to her peers by inserting the South Jutish verb vante "to need" (German: jemandem fehlt etwas) and copying the verbal construction of the South Jutish verb vante (nominative subject - verb - object) into the German surface level (the corresponding verbal construction for the German verb fehlen would have been: benefactive dative - verb nominative subject, as in mir fehlt gar keins).

\section{Example 1: Accommodation}

$\mathrm{A}[1]:$ a vante å jen $a \mathrm{M}$.

[I need one from $\mathrm{M}$ ]

$\mathrm{Y}[2]:$ ich vante gar kein

[I don't need any]

Later on in the same conversation, $\mathrm{Y}$ accommodates even more by changing her matrix language to that of her interlocutors. The bilingual language mode is stressed by the fact that both interlocutors - with South Jutish as their L1 - now insert German lexical items into their South Jutish matrix language.

\section{Example 2: Bi-directional accommodation}

M[1]: vi ska ik arbe mer. a sku spффj fra Astrid om I laue hva hej det no pause (.) det har klingel $t$

[we must not work any more. Astrid told me to ask you if you take a break (.) the bell has rung]

$\mathrm{A}[1]$ : det veej vi jo godt. ja det klingle alligevel $\underline{\mathbf{i}}$ fem minutte hvis vi da ik-nej fordi at weil wir müssen ja auch

[we know that. yes the bell is going to ring in five minutes, if we don't - no because we have to]

Y[2]: vi a lich så godt $i$ gang

[we are working very well at the moment]

In examples 1 and 2, we find bidirectional accommodation as an index of mutual ingroup understanding: the German L1 student (Y) accommodates her matrix language to South Jutish, whereas the South Jutish L1 speakers (M and A) show accommodation by using German insertions. Finally, A code switches to German (weil wir müssen ja auch), while Y code switches to give her comment in South Jutish.

\section{Student- teacher conversation}

In student-teacher conversations, the expected language choice is German, the official school language and the medium of teaching. So in this constellation, the use of any other variety than German may be interpreted as a marked choice in conversations between teacher and student.

To conclude, the unmarked language choice is (i) accommodation to the expected language of teaching (Standard German) and (ii) (uni- or bidirectional) accommodation to the preferred language of one's peers. The latter might imply a code switch and/or switch of matrix language in both directions.

\subsection{Non-accommodation}

The general pattern, the unmarked linguistic choice, is accommodation to the addressee and to linguistic school norms. This needs no explanation, as it is the default and expected linguistic behaviour of the group. Non-accommodation, on the other hand, needs explanation and interpretation. It is striking that (i) non-accommodation occurs only in one direction: from 
German to South Jutish; and (ii) although non-accommodation does occur in the peer group, it occurs predominantly in student-teacher conversation.

\section{Peer group conversation}

Non-accommodation in the peer group is used to mark disagreement and distance. This is shown in example 3. Student 1 (S1) has German as L1, and although Student 2 (S2) would normally accommodate to S1 and speak German, S2 answers in South Jutish. In this way he marks disagreement - not only through the content of his words, but also through his linguistic choice.

\section{Example 3: Non-accommodation}

$\mathrm{S} 1[2]: \mathrm{G} \quad$ ja er ist ganz schön sauer auf uns. [he is angry with us now.]

S2[1]:SJ nej, ik o mae da. a snakke da ma ham.

$\mathrm{S} 1[2]: \mathrm{G} \quad$ ja, ja das kannst du ja gerne. [yes, you can do that if you want.]

\section{Student -teacher conversation}

Although we find a few examples of non-accommodation in the peer group (as in example 3), the most frequent cases of non-accommodation are found in students' conversations with their teachers. These are, for example, cases where the student is irritated by a teacher being too persistent (see example 4) or too impatient (see example 5) with the students.

\section{Example 4: Non-accommodation}

Student [1]:G ja, das weiß ich. [yes, I know.]

Teacher[1]: G weißt du es schon? [do you really know?]

Student [1]:SJ ja, det ha a funden [yes, I have found it]

\section{Example 5: Non-accommodation}

Teacher[1]:G ihr müsst jetzt fertig werden. [you have to finish now]

Student[1]:G heute noch? [today already?]

Teacher[1]:G in zehn minuten. [in ten minutes]

Student[1]:SJ hva'? a a føst he op. [What? I am only up here.]((points to a page in his book))

Teacher[1]:G ja, das nützt alles nichts. wir müssen fertig werden mit dem text. [yes, this is no use. we have to finish this text]

In those minor incidents of disagreement - as shown in examples 4 and 5 - the students quickly return to the expected school language, German. In emotionally more stressful situations, the student may refrain completely from returning to the expected school language.

\section{Example 6: Non-accommodation}

Teacher[2]:G: M., ich möchte nicht mehr. es ist schluss jetzt.

[M. I don't want this any more. it is over now] 
Student [1]:SJ ja, a gee å ue. endda friville.

[Yes, I will leave the class room now. I even volunteer to go]

Teacher[2]:G nein, das ist nicht mehr freiwillig. das kommt auch ins klassenbuch.

[no, this is not voluntarily any more. this will be written in the class book, too]

Student[1]:SJ åååhhrrr!!

Teacher[2]:G ohne was zu malen.

[and don't paint (on the wall)]

Student[1]:SJ ja a mal jo helle ik'.

[but I don't paint]

Concerning example 6, it is important to notice that the teacher does not follow the language switch to South Jutish, and she refuses, simultaneously, to negotiate conditions with this student. Thus, the attempt of the student to negotiate was not successful at all.

The following example (7) shows how a student refuses to go to the front of the class room in order to give his presentation. He wants to give his presentation from his own seat and starts to negotiate conditions with his teacher. In the negotiation, he uses South Jutish, whereas he changes to German as soon as he starts his presentation, from his own seat. In this case, it is clear that he steps out of the expected linguistic frame - a German school lesson in German with a German teacher from Germany (not from the minority) - in order to negotiate conditions "off the record", in this case successfully.

\section{Example 7: Non-accommodation}

Student[1]: SJ nej, a satte ma ik de op. [no I won't sit up there]

Teacher[2]:G nimm bitte platz. [please take your seat]

Student [1]:SJ ja, ka a ik' ba si det he'? [yes, but why can't I just tell it from here?]

Teacher [2]:G bitte F. [please F.]

Student [1]:G ja, am freitag war ich ... ((staying in his own seat )) [last Friday I was...]

To conclude, in the cases of non-accommodation which occur in the examples above, the student wants to gain or take back control in an embarrassing or a vulnerable situation. So he/she steps out of the frame by using the "unofficial" language, hoping to be able to negotiate with the authority on more equal terms.

Teachers may also feel the need in certain situations to step out of their frame and change their social role. In the following example (8) the mathematics teacher wants to show empathy and solidarity with a very quiet girl who is not good at the subject. He steps out of his role as teacher and authority and speaks to her as a friend and helper.

Example 8: Change of social role

Teacher[1]:G K., soll ich dir helfen?

Student[1]:G ja. [K., can I help you?] [yes]

Teacher[1]:SJ så sej da naue, pich. [then say something, girl] 
In this example, the teacher starts out in the school language. However, as he recognises the sad mood of the girl, he switches to South Jutish, signalling solidarity. In this way, he makes it easier for her to accept his help.

In the following two examples ( 9 and 10), we clearly see how a teacher is able to change and redefine his social role by switching from German to South Jutish and back again. The examples come from a discussion where the teacher himself is not responsible for what is going on in the classroom, because the students are busy with a task for another, external person. At the beginning of this stretch of conversation, the teacher steps out of his role as a teacher, choosing the South Jutish dialect to signal this change of social role. Later on, he asks where the external person, who was supposed to be in charge of the class, is. As the students answer that she has left the room, he takes charge of the class and does so by changing to the official language of authority, German ("was macht ihr denn jetzt?").

\author{
Example 9: Change of social role \\ Teacher[1]:SJ hvo a Astrid \\ [Where is Astrid] \\ StudentA[1]:SJ hvem \\ [who] \\ Teacher[1]: $\quad$ Astrid \\ StudentB[1]:SJ hun a gaun igen \\ [she has left again] \\ Teacher[1]:G was macht ihr denn jetzt? \\ [what are you doing now?] \\ StudentA[1]:SJ a laue min einschreibaufgaben for hvordan- a kapeje den ik \\ [I make my home work because how - I don't understand it] \\ Teacher[1]:G Kinder wirklich fertig oder was? \\ [kids ((have)) you finished or what?] \\ StudentA[1]:SJ ja. $a$ einschreibaufgaben forste: $a$ ik richte \\ [yes, but I don't understand the home work]
}

The next example (10) shows a similar pattern of change of language choice and social role: again, the teacher is not responsible for the tasks of the group that is making audio recordings for this project. The students seem to have some technical problems and the teacher changes his role from teacher to a provider of limited technical support. At the beginning of the conversation, he uses the expected official language, German, but discussing the trouble with the audio recorder, he seems to be just as helpless as his students. His change of language seems to stress this lack of expertise. In his lack of technical expertise, he is on equal foot with his students, and his talk with student $\mathrm{C}$ has a very informal, almost private, character. As soon as the problem is solved, he returns to his official role as a teacher with an intrasentential code switch to German: "ok så er det jo alles klar gut."

\title{
Example 10: Change of social role
}

$\begin{array}{ll}\text { StudentA[1]:SJ } & \begin{array}{l}\text { ve do va vos det skal handel om? } \\ \text { [do you know what we work on?] }\end{array} \\ \text { Teacher[1]:G } & \text { nee } \\ \text { StudentA[1]:SJ } & \begin{array}{l}\text { (laughing) a bi a a blomst } \\ \text { [the bee and the flower] } \\ \text { die biene und die blume } \\ \text { [the bee and the flower] }\end{array}\end{array}$




\begin{tabular}{|c|c|}
\hline StudentC[1]:SJ & $\begin{array}{l}g \phi \text { den det no } \\
\text { [does it work now?] }\end{array}$ \\
\hline Teacher[1]:SJ & $\begin{array}{l}\text { ja, no tel den da, it? ste de record jet'l ant stej? } \\
\text { [yes, now it counts, doesn't it? Is 'record' somewhere?] }\end{array}$ \\
\hline StudentC[1]:SJ & $\begin{array}{l}n \phi \\
{[\mathrm{no}]}\end{array}$ \\
\hline Teacher[1]:SJ & $\begin{array}{l}\text { hva' ste den o } \\
\text { [what is on ((the display))?] }\end{array}$ \\
\hline StudentC[1]:SJ & $\begin{array}{l}\text { den de } k \phi \text { ba vie det ste record dee } \\
\text { [it is just going on, there is 'record'] }\end{array}$ \\
\hline Teacher[1]:SJ/G & $\begin{array}{l}\text { ok så } a \text { det jo alles klar gut } \\
\text { [ok. then everything is ok, well] }\end{array}$ \\
\hline
\end{tabular}

To sum up, the examples in 8 to 10 show how the teacher can step out of his official role by changing to the unofficial language. In this way, he can even show lack of expertise, competence and control without losing face. Using a term from critical discourse analysis, one might describe the interaction in terms of symmetrical versus asymmetrical discourses: The use of South Jutish is a way for students and teachers to create - or at least try to create room for symmetrical discourses in the social frame of the school, which is in its fundamental structure characterised by asymmetrical discourses between student and teacher. One might compare the use of the local dialect to a private backyard or a kind of time-out where you can solve problems and negotiate which rights and obligations should be valid for the moment in the "official" world.

On the other hand, divergence from the use of South Jutish for informal conversation and as a means for creating symmetrical discourse is not accepted among the students. This is, of course, a problem for those students who do not belong to the major group of almost balanced bilinguals with South Jutish and German (marked [1] in the transcripts). Being a kind of "substandard" vernacular, South Jutish is a variety which can only be acquired informally in a peer-group or one's neighbourhood; it cannot be learnt through formal teaching. In the German minority school, the students will only be taught the Standard Danish literate language. For children whose parents have immigrated from Germany, this may lead to language problems. In the following example, Student A blames one of his fellow students (B), whose parents moved to Denmark about ten years before, for not speaking the local, South Jutish variety and not trying hard enough to acquire it. It is remarkable, however, that the bilingual Student A categorises his own language, South Jutish, as "Danish", whereas the Standard Danish variety used by Student B - who learns Standard Danish as his L2 at school - is called "københavnsk", Copenhagen Danish. By this categorisation, Standard Danish is marked as the language of the "others" from outside.

\section{Example 11: Divergent language usage}

\begin{tabular}{|c|c|}
\hline StudentA[1]:G & du kannst wenn du willst \\
\hline & [you can if you want to] \\
\hline StudentB[3]:G & ich will nicht- ich kann nicht \\
\hline & [I don't want to - I can't] \\
\hline StudentA[1]:G & ja du tust ja auch nichts dafür \\
\hline SI & [you don't even do anything to learn it] \\
\hline & [the others speak Copenhagen Danish] \\
\hline & $\begin{array}{l}\text { hva ska a si. } \\
\text { [how should I say it] }\end{array}$ \\
\hline
\end{tabular}




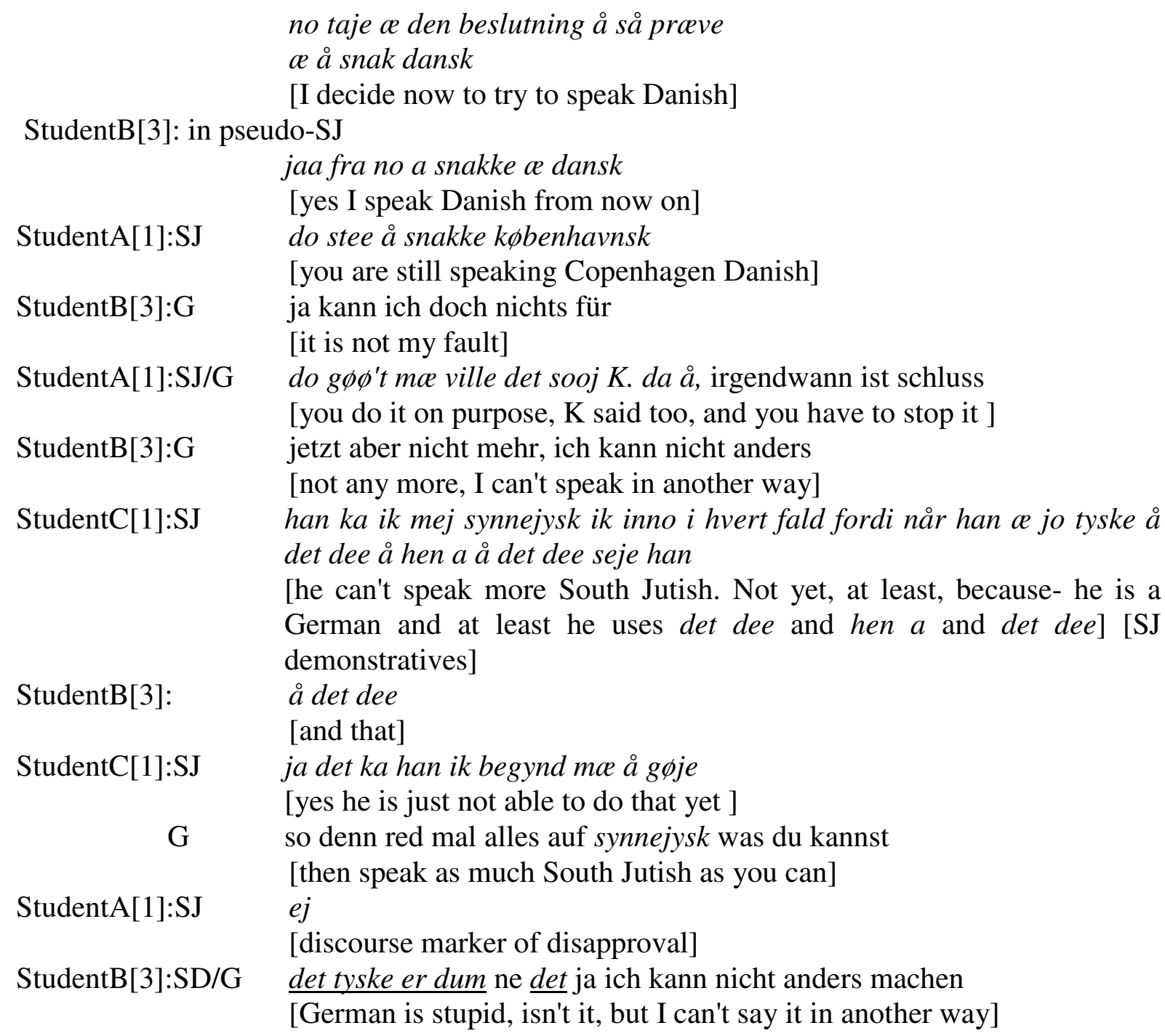

Firstly, this transcript definitely shows us that these bilingual students possess a high degree of metalinguistic awareness. Students $A[1]$ and C[1] even use metalanguage when they discuss Student B[3]'s pronunciation. Examples of this are Student A's quote in Standard Danish "de andre" and Student C's remarks about B's use of the South Jutish demonstratives "det dee". Student B himself tries very hard to produce a qualified and acceptable South Jutish pronunciation, but unfortunately his attempts are not accepted by Student A. The content of B's last remark, however, is of less importance, as German is his mother tongue. However, when confronted with the critique of his fellow students, he tries to produce a kind of shibboleth to show his linguistic loyalty in a presumed accepted language variety. Unfortunately, his attempt is rather futile, so that alone the transcription of his last remark (in Standard Danish) reveals student B's failure relative to the linguistic norm that he aims at.

Secondly, this bit of conversation reveals that the peer group is aware of having a welldefined in-group language norm. Deviations from this norm are not easily accepted by members of the group.

\section{Conclusion}

In German minority schools in the southern part of Denmark, we find a stable bilingual language situation where there are unmarked and marked patterns of bilingual language choice. The pragmatic motivations of code switching show various aspects. Among them we 
find interactional motivations where the code switch to the local vernacular in certain situations is a marked language choice used by students and teachers in order to reduce asymmetries of power. Divergence from this linguistic pattern is, however, not accepted among the peer group of students.

We can conclude from these examples that students and teachers use a local variety as a neutral ground, where they can negotiate which rights and obligations should be valid in the official world. To the teachers, this language offers an opportunity to step out of the social frame without any loss of authority, because the authority is regained as soon as the teacher switches back to the official language. So I would claim so far, that the dialect has got an interactional function in the classroom discourse, mediating between low and high degrees of power.

Within the German minority, this local variety seems to have a mediating function, levelling asymmetries of power between different groups on a micro level. When looking outside the school into the surrounding community, we find a similar pattern: the German minority in Denmark has German as its official language and South Jutish as its unofficial "pyjama"language. Some of the leading persons of the German minority put it this way: "we speak German when we stand up, South Jutish when we sit down". Within the Danish majority, however, South Jutish is a low-prestige language compared to Standard Danish, more in line with the results of Maegaard's (2001, 2007) sociolinguistic matched guise tests. However, when a person from the German minority speaks to persons from the local Danish majority, they will both prefer South Jutish as a common language - as their lingua franca, as most of the local people from the Danish majority in the southern part of the region still speak South Jutish as one of their oral varieties. The reason for this status as a lingua franca is that South Jutish is not a nationally marked language (like Standard German or Standard Danish). Using this classic vernacular, one may meet on a nationally neutral linguistic ground and avoid both linguistic conflicts and linguistic attempts at over-adjustment. It has been said that globalisation, at the same time, leads to regionalisation. I doubt whether this holds true from a linguistic point of view. But even in times of globalisation, you may find this kind of linguistic utopia of power-free and nationally unmarked discourses on a regional level.

The research reported in this paper deals with a very small, non-prestigious language (South Jutish) with only about 150,000 speakers. My hypothesis is as follows: when a person in a plurilingual society has a range of language resources and uses these in his or her daily life, a linguistic pattern will develop in a bi- or multilingual speech community (such as the school in which we collected our data). The pupils use the dialect for internal peer group conversations, but also in conversations with their teachers to mark disagreement and in critical and stressful situations where they want to regain control over the situation or negotiate "for free".

Recently, Myers-Scotton and Jake (2009) used the phrase "no chaos allowed" to describe the grammatical structure of bilingual speech. I would like to extend this phrase to apply to the language usage of bilinguals, as well. In a stable speech community you will be able to find pragmatic norms and rules for code switching: the harder you look at the bilingual speech data of a certain language community, the more you find rules and norms. These rules may not have a universal character, such as that of the rules of the grammatical structure of bilingual speech, because every speech community will probably develop its own rules. However, my claim is that these data of a bi- or multilingual speech community strengthen the hypothesis that "no chaos is allowed" in bilingual language usage, either. It should also be clear that attempts to impose a norm of "double monolingualism" or of linguistic purity on 
these students would in fact reduce their rich pragmatic capacity and their multifaceted way of expressing themselves.

\section{Acknowledgements}

The research project "Divergierender Sprachgebrauch bei bilingualen Jungendlichen" was funded by the Deutsche Forschungsgemeinschaft - DFG. My colleagues in this project were Astrid Westergaard and Karoline Kühl. I would like to thank Astrid Westergaard for collecting and transcribing the data and my colleague, Hartwig Eckert, for inspiring discussions.

\section{Notes}

1. The German minority in Denmark and the Danish minority in Germany can be described as historical, regional minorities that became minorities in their present host countries when the multilingual and multinational region, the Duchy of Schleswig, was divided into two parts by a national border line between Denmark and Germany in the year 1920. These two minorities are national minorities, but not language minorities in the traditional sense of the word, because the vernaculars Low German, South Jutish and Frisian were the dominating spoken varieties for centuries.

\section{References}

Auer, P. 1995. The pragmatics of code-switching: A sequential approach. In L. Milroy and P. Muysken (eds). One speaker, two languages. Cross-disciplinary perspectives on codeswitching. Cambridge: Cambridge University Press. pp. 115-135.

Fredsted, E. 2003. The decline of a minor language - from a transnational vernacular to an endangered dialect of minorities. In T. Stolz and Joel Scherzer (eds). Minor languages coming to grips with a suitable definition. Bochum: Universitätsverlag Dr. N. Brockmeyer. pp. 41-58.

Fredsted, E. 2008a. "We make such a mishmash". Bilingual language usage in class room peer group talk. In M. Pütz and J.-A. Neff van Aertselaer (eds). Contrastive pragmatics: Interlanguage and cross-cultural perspectives. Berlin/New York: Mouton de Gruyter. pp. 177-203.

Fredsted, E. 2008b. Convergence in verb phrases. Linguistics 46(5): 949-982.

Grosjean, F. 2001. The bilingual's language modes. In J. Nicol (ed.) One mind, two languages - bilingual language processing. Oxford: Blackwell. pp. 1-25.

Gumperz, J.J. 1982. Discourse strategies. Cambridge: Cambridge University Press.

Gumperz, J.J. 1992. Contextualization revisited. In P. Auer and A. di Luzio (eds). The contextualization of language. Amsterdam/Philadelphia: Benjamins. pp. 39-53.

Kühl, K. 2008. Bilingualer Sprachgebrauch bei Jugendlichen im deutsch-dänischen Grenzland. Hamburg: Verlag Dr. Kovac.

Maegaard, M. 2001a. Sprogholdninger hos sønderjyske unge. In M. Kunøe and P. Widell (eds). Mфde om udforskningen af dansk sprog. Aarhus: Aarhus Universitet. pp. 217-226.

Maegaard, M. 2001b. 'Jeg er da stolt af at jeg er sønderjyde - altså sådan forholdsvis!' Om sprogbrug og sprogholdninger hos sønderjyske unge. Danske Talesprog 2, pp. 77-166..

Myers-Scotton, C. 1993. Social motivations for codeswitching - Evidence from Africa. Oxford: Clarendon Press.

Myers-Scotton, C. 1998. Codes and consequences: Choosing linguistic varieties. New York: Oxford University Press. pp. 3-17

Myers-Scotton, C. 2002. Contact linguistics: Bilingual encounters and grammatical outcomes. Oxford: Oxford University Press. 
Myers-Scotton, C. and J.L. Jake. 2009. Universal structure in code-switching and bilingual processing and production. In B. Bullock and J.A. Toribio (eds). Handbook of code switching. Cambridge: Cambridge University Press. pp. 336-358.

Westergaard, A. 2008. Strukturelle und pragmatische Verwendungsmuster im bilingualen Sprachgebrauch bei Jugendlichen. Hamburg: Verlag Dr. Kovac. 